\title{
Role of Auxins on Rooting of Different Types of Cuttings in Fig
}

\author{
Hiral R. Patel* and M.J. Patel \\ Department of Horticulture, B. A. College of Agriculture, Anand Agriculture University, \\ Anand-388110, Gujarat, India \\ *Corresponding author
}

\section{A B S T R A C T}

\section{Keywords}

IBA, NAA, Hard wood cutting, Semi hard wood cutting, Fig

Article Info

Accepted:

12 February 2018

Available Online:

10 March 2018
The study was conducted at College Nursery, Department of Horticulture, B. A. College of Agriculture, AAU, Anand to evaluate auxins on different types of stem cuttings. Two different auxins like IBA, NAA at 2000, 4000 and $6000 \mathrm{mg} \mathrm{l}^{-1}$ were applied to the hard and semi hard wood cuttings with control and absolute control. Among the different treatments, maximum root growth in respect to rooting percentage i.e. 66.24 and 82.57 per cent, number of primary roots $(7.20,12.34)$, root length $(6.57$ and $12.04 \mathrm{~cm})$, dry weight $(0.63$ and $0.84 \mathrm{~g})$ of root were observed in hardwood cutting treated with IBA $4000 \mathrm{mg}^{-1}$ at 30 and 60 DAP, respectively. Similarly, shoot growth in respect of length of shoot (5.20, $9.34 \mathrm{~cm}$ ) and number of shoots per cutting were also observed maximum in hardwood cutting treated with IBA $4000 \mathrm{mg} \mathrm{l}^{-1}$ at 30 and 60 DAP, respectively. While, minimum numbers of days taken for sprouting i.e. 12.27 days and survival percentage i.e. 76.9 per cent were observed maximum in hardwood cutting treated with IBA $4000 \mathrm{mg} \mathrm{l}^{-1}$.

\section{Introduction}

Fig (Ficus carica L.) is an important deciduous fruit crop in tropical and subtropical countries and belongs to family Moraceae. Fig has antipyretic, diuretic and aphrodisiac properties are reported natural tonic for energy and vitality.

Figs are one of the richest plant sources of calcium and fiber, besides dried figs are rich source of fiber, copper, manganese, magnesium, potassium, calcium and vitamin $\mathrm{K}$. It is propagated by both sexual and asexual method of propagation. Fig plants can be propagated from seeds extracted from dried fruits. The zygotic seedlings usually are not true to type and are employed only to breed new varieties. Fig is commercially propagated by cuttings in India. With cuttings vigorous saleable plants can be produced in less than one year. Root promoting hormones play important role in the success of rooting of cuttings.

The most commonly used growth regulators are auxins which are essential for process of rooting, possibly because they stimuli the ethylene synthesis, thus favoring rooting. The substances most commonly used for better rooting in cuttings of various plants are indole butyric acid (IBA), indole acetic acid (IAA) and naphthalene acetic acid (NAA) with varied concentration. The problem lies in very 
low or undesirable percentage of success. Keeping in view, this investigation was carried out to see the role of auxins on rooting of different types of cuttings in fig.

\section{Materials and Methods}

The present investigation was conducted under net house in College Nursery, Horticultural Research Farm, Department of Horticulture, B. A. College of Agriculture, AAU, Anand during 2015. A hardwood cutting of fig was taken from one year old shoots which were cut to have 4-5 nodes each. The length of cuttings used for planting was $20-22 \mathrm{~cm}$. The basal end of the cuttings was given a slanting cut to expose maximum absorbing surface for effective rooting. While, semi hardwood cutting was taken from the current season's growth. The leaves were removed from the cuttings and trimmed to the required length by removing the terminal portions just above a bud. The experiment was laid out in Completely Randomized Design with 3 repetitions. The treatments were IBA (2000, 4000, $6000 \mathrm{mg} \mathrm{l}^{-1}$ ), NAA (2000, 4000, $6000 \mathrm{mg} \mathrm{l}^{-1}$ ), distilled water without growth regulator (control) and absolute control.

The prepared cuttings were treated with plant growth regulators by quick dip method for 25 seconds and allowed to dry for 15 minutes and then planted in sand media. After 30 and 60 days of planting, the cuttings were uprooted carefully from the sand bed without damaging the roots and washed in water. The percentage of rooting, average number of roots and shoots per cutting, length of the longest root, number of shoots per cutting, dry weight of root and shoot were recorded. For the survival percentage of rooted cuttings, 20 rooted cuttings after 60 days of plants were transplanted in poly bags containing garden soil and well-rotted FYM. The survival percentage of transplants was recorded 3 weeks after transplanting.

\section{Results and Discussion}

\section{Number of days taken for sprouting}

Observations on number of days taken for sprouting (Table 1) differed significantly among different of types of cutting and auxins concentration. Hardwood cutting with IBA $4000 \mathrm{mg}^{-1}$ recorded minimum number of days (12.27) taken for 50\% sprouting and it was at par with hardwood cutting with NAA $4000 \mathrm{mg}^{-1}$ i.e. 14.47 days.

Maximum number of days (48.00) taken for sprouting was recorded under semi hardwood cutting with absolute control. This might be due to synergic effect of IBA and type of cutting. The present investigation is in conformity with the results reported by Khapare et al., (2012) in fig cv. Dinkar.

\section{Rooting percentage}

Hardwood cutting with IBA $4000 \mathrm{mg} \mathrm{l}^{-1}$ recorded the highest percentage of rooting i.e. 66.24 and $82.57 \%$ at 30 and 60 DAP in that order. The minimum percentage of rooted cuttings i.e. 19.47 and $25.20 \%$ was recorded under the treatment combination semi hardwood cutting with absolute control at 30 and 60 DAP, respectively. This might be due to the fact that hardwood cutting contain more starch which in turn bring about favorable conditions for root initiation and more rooting percentage coupled with positive response of IBA. The present finding is in conformity with Reddy et al., (2008 b) in fig.

\section{Number of primary roots}

Number of roots per cutting at 30 DAP, hardwood cutting with IBA $4000 \mathrm{mg} \mathrm{l}^{-1}$ recorded highest number of primary roots (7.20) per cutting as compared to rest of the treatments, similar result was also found at 60 DAP (Table 1). 
Table.1 Effect of auxins on number of days taken for sprouting, rooting percentage, number of roots and root length on hard wood and semi hard wood stem cuttings of fig

\begin{tabular}{|c|c|c|c|c|c|c|c|}
\hline \multirow[t]{2}{*}{ Treatments } & \multirow[t]{2}{*}{ Sprouting days } & \multicolumn{2}{|c|}{ Rooting percentage } & \multicolumn{2}{|c|}{ Number of roots } & \multicolumn{2}{|c|}{ Root length (cm) } \\
\hline & & 30 DAP & 60 DAP & 30 DAP & 60 DAP & 30 DAP & 60 DAP \\
\hline Hardwood + IBA $2000 \mathrm{mg} \mathrm{l}^{-1}$ & 16.74 & 52.90 & 74.60 & 4.60 & 9.64 & 5.71 & 9.17 \\
\hline Hardwood + IBA $4000 \mathrm{mg} \mathrm{l}^{-1}$ & 12.27 & 66.24 & 82.57 & 7.20 & 12.53 & 6.57 & 12.04 \\
\hline Hardwood + IBA $6000 \mathrm{mg} \mathrm{l}^{-1}$ & 22.54 & 58.54 & 68.60 & 4.14 & 9.40 & 4.66 & 7.06 \\
\hline Hardwood + NAA $2000 \mathrm{mg} \mathrm{l}^{-1}$ & 15.07 & 52.68 & 70.54 & 4.27 & 9.39 & 5.04 & 7.96 \\
\hline Hardwood + NAA $4000 \mathrm{mg} \mathrm{l}^{-1}$ & 14.47 & 57.84 & 76.50 & 6.34 & 10.34 & 6.11 & 9.12 \\
\hline Hardwood + NAA $4000 \mathrm{mg} \mathrm{l}^{-1}$ & 23.67 & 50.87 & 67.87 & 3.80 & 8.54 & 4.26 & 6.64 \\
\hline Hardwood + Water dipping (control) & 27.00 & 32.00 & 44.37 & 2.40 & 5.47 & 1.78 & 3.08 \\
\hline Hardwood + Absolute control & 32.67 & 25.67 & 35.14 & 2.13 & 5.34 & 1.25 & 2.29 \\
\hline Semi hardwood + IBA $2000 \mathrm{mg} \mathrm{l}^{-1}$ & 33.60 & 47.64 & 58.44 & 3.34 & 8.74 & 3.02 & 7.04 \\
\hline Semi hardwood + IBA $4000 \mathrm{mg} \mathrm{l}^{-1}$ & 23.87 & 51.70 & 63.90 & 4.60 & 9.40 & 4.54 & 9.23 \\
\hline Semi hardwood + IBA $6000 \mathrm{mg} \mathrm{l}^{-1}$ & 34.60 & 47.50 & 54.94 & 3.00 & 7.27 & 3.30 & 5.89 \\
\hline Semi hardwood + NAA $2000 \mathrm{mg} \mathrm{l}^{-1}$ & 26.80 & 47.24 & 57.77 & 3.74 & 7.48 & 3.15 & 6.64 \\
\hline Semi hardwood + NAA $4000 \mathrm{mg} \mathrm{l}^{-1}$ & 26.94 & 47.27 & 64.77 & 3.80 & 7.94 & 3.60 & 8.16 \\
\hline Semi hardwood + NAA $4000 \mathrm{mg} \mathrm{l}^{-1}$ & 32.60 & 41.20 & 49.90 & 2.20 & 5.94 & 2.25 & 5.05 \\
\hline $\begin{array}{l}\text { Semi hardwood + Water dipping } \\
\text { (control) }\end{array}$ & 44.60 & 22.20 & 30.44 & 1.27 & 3.14 & 1.16 & 1.98 \\
\hline Semi hardwood + Absolute control & 48.00 & 19.47 & 25.20 & 0.73 & 2.67 & 0.96 & 1.34 \\
\hline S.Em \pm & 0.77 & 1.19 & 0.64 & 0.19 & 0.25 & 0.13 & 0.14 \\
\hline C.D. at $5 \%$ & 2.21 & 3.45 & 1.86 & 0.56 & 0.74 & 0.39 & 0.40 \\
\hline
\end{tabular}


Table.2 Effect of auxins on number of shoots, shoot length, dry weight of roots and survival percentage of hard wood and semi hard wood stem cuttings of fig

\begin{tabular}{|c|c|c|c|c|c|c|c|}
\hline \multirow[t]{2}{*}{ Treatments } & \multicolumn{2}{|c|}{ Number of shoots } & \multicolumn{2}{|c|}{ Shoot length (cm) } & \multicolumn{2}{|c|}{ Dry weight of root (g) } & \multirow{2}{*}{$\begin{array}{l}\text { Survival } \\
\text { percentage }\end{array}$} \\
\hline & 30 DAP & 60 DAP & 30 DAP & 60 DAP & 30 DAP & 60 DAP & \\
\hline Hardwood + IBA $4000 \mathrm{mg} \mathrm{l}^{-1}$ & 2.34 & 7.26 & 5.20 & 9.34 & 0.63 & 0.84 & 76.9 \\
\hline Hardwood + IBA $6000 \mathrm{mg} \mathrm{l}^{-1}$ & 1.54 & 4.13 & 3.72 & 6.74 & 0.45 & 0.54 & 63.6 \\
\hline Hardwood + NAA $4000 \mathrm{mg} \mathrm{l}^{-1}$ & 1.87 & 5.53 & 4.24 & 7.52 & 0.45 & 0.71 & 66.5 \\
\hline Hardwood + NAA $6000 \mathrm{mg} \mathrm{l}^{-1}$ & 1.40 & 4.14 & 3.43 & 5.94 & 0.29 & 0.47 & 53.5 \\
\hline Hardwood + Water dipping (control) & 0.86 & 1.93 & 2.27 & 3.22 & 0.21 & 0.21 & 24.3 \\
\hline Hardwood + Absolute control & 0.66 & 1.60 & 1.40 & 2.00 & 0.14 & 0.36 & 19.1 \\
\hline Semi hardwood + NAA $2000 \mathrm{mg} \mathrm{l}^{-1}$ & 1.34 & 3.20 & 3.42 & 5.84 & 0.32 & 0.48 & 39.1 \\
\hline Semi hardwood + NAA $4000 \mathrm{mg} \mathrm{l}^{-1}$ & 1.80 & 4.80 & 3.81 & 6.70 & 0.39 & 0.50 & 46.9 \\
\hline Semi hardwood + NAA $6000 \mathrm{mg} \mathrm{l}^{-1}$ & 0.93 & 2.86 & 3.10 & 5.14 & 0.29 & 0.44 & 34.7 \\
\hline $\begin{array}{l}\text { Semi hardwood + Water dipping } \\
\text { (control) }\end{array}$ & 0.54 & 1.20 & 1.32 & 1.96 & 0.18 & 0.24 & 18.4 \\
\hline Semi hardwood + Absolute control & 0.34 & 0.86 & 0.93 & 1.11 & 0.11 & 0.12 & 11.0 \\
\hline S.Em \pm & 0.13 & 0.17 & 0.06 & 0.10 & 0.04 & 0.02 & 0.86 \\
\hline C.D. at 5\% & NS & 0.49 & 0.19 & 0.29 & 0.11 & 0.05 & 2.47 \\
\hline
\end{tabular}


Application of auxins affected the regeneration of roots on cuttings. Auxin, in general, promotes rooting of stem cuttings. The effectiveness, however, varies with the nature and concentration of auxin (Hartman et al., 2011). There was reverse trend in number of roots with increasing concentration of auxin. The results obtained were in conformity with Hore and Sen (1992) in fig and Upadhyay and Badyal (2007) in pomegranate.

\section{Root length}

The highest length of root was observed in hardwood cutting with IBA $4000 \mathrm{mg} \mathrm{l}^{-1}$ i.e. 6.57 and $12.04 \mathrm{~cm}$ as compared to rest of the treatments, but the least length i.e. 0.96 and $1.34 \mathrm{~cm}$ of root was observed in semi hardwood cutting with absolute control at 30 and 60 DAP, respectively (Table 1). The increase in root length may be due to cuttings treated with IBA application has been found to enhance the histological features like formation of callus and tissue and differentiation of vascular tissue. It has also effect on the metabolites translocation and carbohydrates metabolism. The results are in close proximity to the findings of Reddy et al., (2008 a) in fig and Santos et al., (2011) in Annona muricata.

\section{Number of shoots}

Significantly maximum number of shoots (7.26) was recorded in the combination of hardwood cutting treated with IBA $4000 \mathrm{mg}$ $1^{-1}$ as compared to rest of the treatments. Minimum number of shoots (0.86) was observed in semi hardwood cutting with absolute control at 60 DAP (Table 2). It might be due to co-effect of type of cutting and auxin concentrations. The results are conformity with Siddiqui and Hussain (2007) in Ficus hawaii cutting treated with IBA 4000 $\mathrm{mg} \mathrm{l}^{-1}$.

\section{Shoot length}

The longest shoot length i.e. 5.20 and $9.34 \mathrm{~cm}$ was observed in hardwood cutting treated with IBA $4000 \mathrm{mg} \mathrm{l}^{-1}$ and the lowest shoot length i.e. 0.93 and $1.11 \mathrm{~cm}$ was observed in semi hardwood cutting with absolute control at 30 and 60 DAP, respectively. It might be due to positive effect between the type of cuttings and auxin levels. Above result is in conformity with the findings of Ramos et al., (2008) in fig.

\section{Dry weight of root}

The maximum dry weight of root i.e. 0.63 and $0.84 \mathrm{~g}$ was recorded in hardwood cutting treated with IBA $4000 \mathrm{mg} \mathrm{l}^{-1}$, while the minimum weight was in semi hardwood cuttings with absolute control (C2A8) i.e. 0.11 and $0.12 \mathrm{~g}$ at 30 and $60 \mathrm{DAP}$, respectively. It might be due to hardwood cutting contain more stored carbohydrate coupled with combination of IBA increased the number of roots resulting in higher fresh and dry weight. These findings are in conformity with Zarei et al., (2014) in Ficus benjamina var. Starlight.

\section{Survival percentage}

Hardwood cutting treated with IBA $4000 \mathrm{mg}$ $1^{-1}$ recorded significantly the highest survival percentage i.e. $76.9 \%$ at 3 weeks after planting as compared to rest of the treatments. This might have resulted from development of effective root system and increase in number and length of roots per cutting which might have influenced the uptake of water and nutrients. The present investigation is in conformity with findings of Reddy et al., (2008 a) in fig.

From the results it can be concluded that hardwood cutting treated with IBA $4000 \mathrm{mg}$ $1^{-1}$ in quick dip method recorded maximum 
percentage of rooting, survival percentage, shoot and root characters over semi hardwood cutting. Thus, fig can be propagated by hardwood cutting treated with IBA $4000 \mathrm{mg}$ $1^{-1}$ for early growth.

\section{References}

Hartmann, H. T., Kester, D. E., Davies, F. T., Geneve, R. L. 2011. Plant Propagation: Principles and Practices, $8^{\text {th }}$ Ed. Prentice Hall of India Pvt. Ltd., Boston.

Hore, J. K and Sen, S. K. 1992. Root regeneration in air layers of fig (Ficus carica L.). CAB Abstract: 10 (3), 726729.

Khapare, L. S., Dahale, M. H. and Bhusari, R. B. 2012. Propagational studies in fig as affected by plant growth regulator. Asian J. Hort. 7(1):118-120.

Ramos, D. P.; Leonaand, S and Junior, E. R. D. (2008). Evaluation of the cutting time and growth regulators in fig cuttings. Rev. Bras. Frutic., 30(3): 748753.

Reddy, K. V. R., Reddy, P. and Goud, P. V. 2008 a. Effect of auxins on rooting of fig (Ficus carica L.) hardwood and semi hardwood cuttings. Indian $J$. Agric. Res., 42(1): 75-78.

Reddy, K. V. R., Reddy, P. and Goud, P. V. $2008 \mathrm{~b}$. Role of auxins synergists in the rooting hardwood and semi hardwood cuttings of fig (Ficus carica L.). Indian J. Agric. Res., 42(1): 47-51.

Santos, M. Q. C., Lemos, E. E. P., Salvador, T. L., Rezende, L. P. and Silva, J. W. 2011. Rooting soft cuttings of soursop (Annona muricata) 'Giant of alagoas'. Acta Horticulture, 923.

Siddiqui, M. I. and Hussain, S. A. 2007. Effect of IBA and types of cuttings on root initiation of Ficus hawaii. Sarhad J. Agric. 23(4): 919-926.

Upadhyay, S. K. and Badyal, J. 2007. Effect of growth regulators on rooting of pomegranate (Punica granatum L.) cutting, Haryana J. Hort. Sci., 36 (1-2): 58-59.

Zarei, H., Babaie, H. and Hemmati, K. 2014. Propagation of Ficus benjamina var, Starlight by stenting technique under different concentrations of IBA in various times of taking cutting. J. Orna. Pl., 4(2): 75-79.

\section{How to cite this article:}

Hiral R. Patel and Patel, M.J. 2018. Role of Auxins on Rooting of Different Types of Cuttings in Fig. Int.J.Curr.Microbiol.App.Sci. 7(03): 1317-1322.

doi: https://doi.org/10.20546/ijcmas.2018.703.157 